\title{
Research on the Mass Destruction in Landscape Environment
}

\author{
Yao $\mathrm{Li}^{1}$, Yonggang $\mathrm{An}^{1,}{ }^{*}$, Wenwu Chen ${ }^{1}$ and Chang Zhao ${ }^{2}$ \\ ${ }^{1}$ Beinong Road 7, Huilongguan Town, Changping District, Beijing City, China \\ ${ }^{2}$ Chinese Academy of Forestry, Dongxiaofu $1^{\text {st }}$, Haidian District, Beijing City, China \\ Corresponding author
}

\begin{abstract}
This paper start to mine the four root causes of vandalism generating in landscape environment from four angles including the designers, constructor, users and environment; and then through analyzing and sorting, collate the specific form of vandalism grouped into five areas; at last, based on the five forms, sum seven solutions to specific issues.
\end{abstract}

\section{Keywords-landscape; vandalism; designer; solution}

\section{I.INTRODUCTION}

In recent years the reports abound about the mass destruction which brings about landscape ornamental quality decline, environmental pollution in. Some time ago reported that the palace in 300 tanks was lovers lettering; large Numbers of tourists appreciate cherry blossoms and produce litter pollution in water into PingBa County in Red Maple Lake. Such as the variety of vandalism, there are many in our life.

$\mathrm{Xu}$ an (2004) argues that general principles of landscape design to prevent the destruction of the vitality, suitability, rich feeling, management, and fair this four aspects [1]. In addition, in the fourth chapter of the open public space and public behavior research, the scholar Zhineng Liu of Tian Jin University put forward several measures to solve the vandalism, such as appropriate design, perfect the management system, and strengthen induced behavior [2]. Most of these studies give a guidance of landscape design from the perspective of the human environment behavior and summing conceptual solutions.

\section{II.THE CAUSES AND MANIFESTATION OF DESTRUCTION IN LANDSCAPE}

\section{A. Destruction Causes}

From the subjective and objective factors related to landscape design considerations, including the designer, contractor, users and environment, the paper sums up the four causes of disruptive behavior.

1) The lack of humanized design: In recent years, some cities blindly build commercial street in the center of the city, causing people cross traffic, traffic chaos, residents loss of open space, human nature have a rest not satisfied, returning the "thousand city side" of urban landscape.

2) Different degree of man-made destruction: The understanding of human behavior belongs to behavioral science [3]. In the world, there are many kinds of schools of psychology research, such as Freud psychology, Tower of psychology, Jungian psychology, etc.

Moravian Freud (1856-1856) stressed that the actions of people in the unconscious mind is of Paramount importance and put forward the theory of the subconscious mind. Compared with Freud, Jung (1875 The Swiss) more emphasis that the individual's unconscious, he found a society or the collective unconscious, called the "collective unconscious".It has important arguments for analyzing landscape destruction of human unconscious herd behavior. Respectively from the perspective of naturalism level and spirit level revenge, these two kinds of behavior view have direct guiding significance for research on human behavior.So man-made destruction has different influence on garden environment in TABLEI.

TABLE I. DISRUPTIVE BEHAVIOR CLASSIFICATION.

\begin{tabular}{|c|l|l|l|l|}
\hline Order & Level & \multicolumn{1}{|c|}{ name } & \multicolumn{1}{c|}{ explain } & \multicolumn{1}{|c|}{ case } \\
\hline A & Light & $\begin{array}{l}\text { The unconscious herd } \\
\text { behaviorI }\end{array}$ & $\begin{array}{l}\text { Generally it refers to the user's unconscious state, and mass } \\
\text { consistency, characteristics to mass destruction. }\end{array}$ & $\begin{array}{l}\text { The decapitation of flowers and plants; litter; } \\
\text { lawn held a square dance, a family meal }\end{array}$ \\
\hline B & Medium & $\begin{array}{l}\text { Reverse behavior of } \\
\text { design evaluation }\end{array}$ & $\begin{array}{l}\text { It refers that the performance of the landscape environment } \\
\text { effect is difficult to satisfy the basic requirement of the } \\
\text { user, thus producing the reverse vandalism. }\end{array}$ & $\begin{array}{l}\text { Inclined to wear intersection green space; } \\
\text { Across the road green belts; The lack of } \\
\text { accessible design }\end{array}$ \\
\hline C & Heavy & $\begin{array}{l}\text { Pressure relief type } \\
\text { vandalism }\end{array}$ & $\begin{array}{l}\text { Generally it refers to the user's stress and emotional vent } \\
\text { release in landscape environment, the resulting damage to } \\
\text { the environment. }\end{array}$ & $\begin{array}{l}\text { Pavilion's scribble on the column picture; } \\
\text { Damage identification card; Damage to the } \\
\text { bench, seat }\end{array}$ \\
\hline
\end{tabular}

3) Lack of the botanical garden construction and later maintenance: With the blind pursuit of construction speed and considerable economic benefits, there are a lot of hidden trouble in quality in landscape construction and the late maintenance, sooner or later, playing their part in mass destruction.
4) Environmental labeling system boot is not clear: Labeling system belongs to the important part of the garden environment, through guiding, instructions, warning, three aspects, to provide people of environmental labeling system. But due to the inappropriate label height, unreasonable place, it cause labeling system without hierarchy and integrity, and 
has difficult to determine the accurate position in the landscape, unclear destination, eventually attract the public's destruction. Between The horizontal distance (D) and the vertical height $(\mathrm{H})$ of lowest sign on markers, the ratio is not appropriate, such as signs and users too close, no block, will cause the user scribble on the label content, even aside its disassembly.

\section{B. Different Forms of Vandalism}

1) The destruction of landscape construction column and the exterior walls: The destruction of masses in landscape architecture is mainly in two aspects: pillar lettering and thus graffito of the scribble in building exterior wall poster (different in wall painting).

2) Garden green land and vegetation destruction: Expression of user destruction in green land and vegetation is not the same in different landscape space, mainly embodied in the following several kinds of landscape types:

a) Residential green space: Mainly in residential end type back yard area is less than $12 \mathrm{~m} * 12 \mathrm{~m}$, vehicles enter are forced to crush to the kurb and green land; The loop less than $4 \mathrm{~m}$, roads inside the village not in conformity with the specifications.

b) The urban public open space: Pavement square scale greatly, green coverage rate low, in result the rate can't meet the needs of the masses.

c) The park green space: The most common is that a lot of families play with children in the park, inadvertently trampling on the integrity of the lawn; in the evening hold a bonfire party together on green space, destroying the microclimate of park green space(FIGUREI).

d) Campus green space: Through the planning road map and students use contrast figure, the green spaces of the side on the road intersection are often inclined to be crossed, crushed out a "the nearest way to its destination. These made green space damaged, loss of the surrounding vegetation growth, plant landscape integrity lost, as shown in FIGUREI.
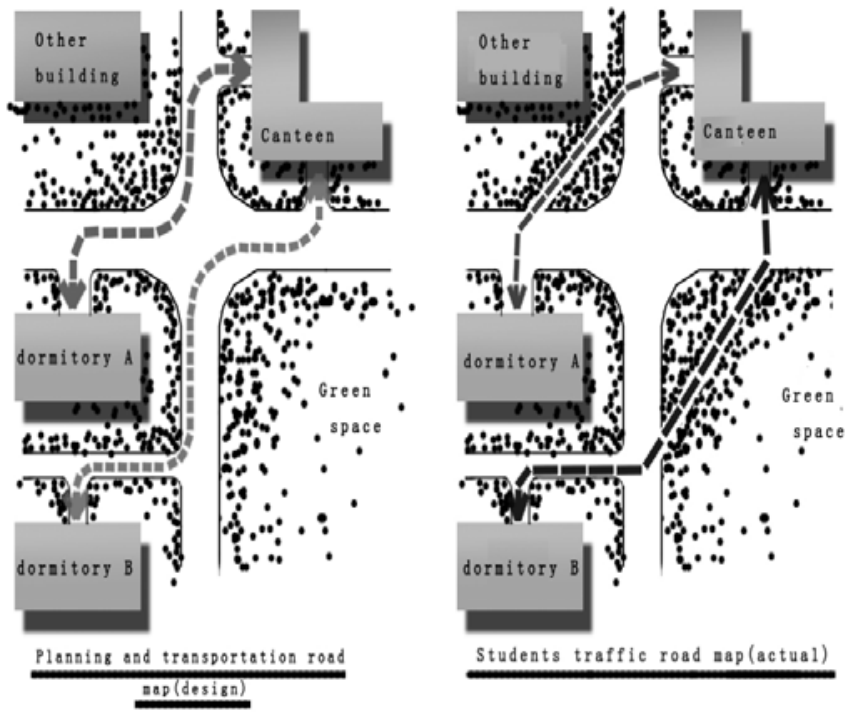

FIGUREI. THE CAMPUS TRAFFIC ANALYSIS.

3) The destruction of Garden sketch and the elements:Outdoor benches seats are damaged, the sculptures are blotted out, and so on; lack of barrier-free design, building entrance and wicket such steps are man-made destructed by the wheelchair.

4) Water damage:Damage mainly displays in water eutrophication, the self-purified capacity of water environment destroyed and waterfront lawn dominated by activity. There is a difference in the performance of the way of users with different age groups damaging marina green water. The scope of urban activities is related to the radius of the travel time, activity and related travel range, so this is of great significance to research the damage to the marina green water(TABLEII).

5) Green land destruction:It mainly embodied in the popular across the road green belts. Design of green vegetation level is not rich which is only with tall trees cover and shrub stratum, insufficient design of small trees, and bring an opportunity to the public through the green belts.

TABLE II. WATERFRONT GREEN SPACE ANALYSIS

\begin{tabular}{|l|c|l|l|l|}
\hline \multicolumn{1}{|c|}{ Users } & Radius of waterfront activities & \multicolumn{1}{|c|}{ Space type } & \multicolumn{1}{|c|}{ space } \\
\hline $\begin{array}{l}\text { Young } \\
\text { people }\end{array}$ & $260-300 \mathrm{~m}$ & Hydrophilic space & $\begin{array}{l}\text { The shore water, such as pro level stage, into } \\
\text { the water the lawn }\end{array}$ & $\begin{array}{l}\text { Into the water on the snacks } \\
\text { garbage }\end{array}$ \\
\hline $\begin{array}{l}\text { Middle-aged } \\
\text { people }\end{array}$ & $220-260 \mathrm{~m}$ & Near water space & $\begin{array}{l}\text { Waterfront zonal greenbelt, such as ribbon } \\
\text { grass, strip center square }\end{array}$ & Tents, picnic on the lawn \\
\hline $\begin{array}{l}\text { Older } \\
\text { population }\end{array}$ & $180-220 \mathrm{~m}$ & Far water space & $\begin{array}{l}\text { Waterfront along activity space, such as, small } \\
\text { scale space under the tree }\end{array}$ & $\begin{array}{l}\text { Shade is put tables and chairs, play } \\
\text { chess, play cards }\end{array}$ \\
\hline
\end{tabular}

\section{III.COUNTERMEASURES OF VANDALISM IN LANDSCAPE}

\section{A. Vertical Greening of Building Facades}

Vertical greening soften the outline of the building curt, and form the overall unified style with plane greening. The tall building surface can choose the type of Boston ivy which has strong growth ability; for low building facade grow ficus pumila, winding stone, fu fang cane and dedicated, and so on.

\section{B. Reserve Function and Traffic Space}

In urban open space reserve pressure, the boxing gloves, sand wall, bunkers, for residents to unleash pent-up emotions inside; In the campus landscape design, the area of pavement paving surface increase to $25-30 \mathrm{M}^{2}$ in local intersection; according to the volume of traffic planning $1.2-2.0 \mathrm{M}$ wide oblique garden road, it set aside convenient traffic space and the fast track, as shown in FIGUREII. 

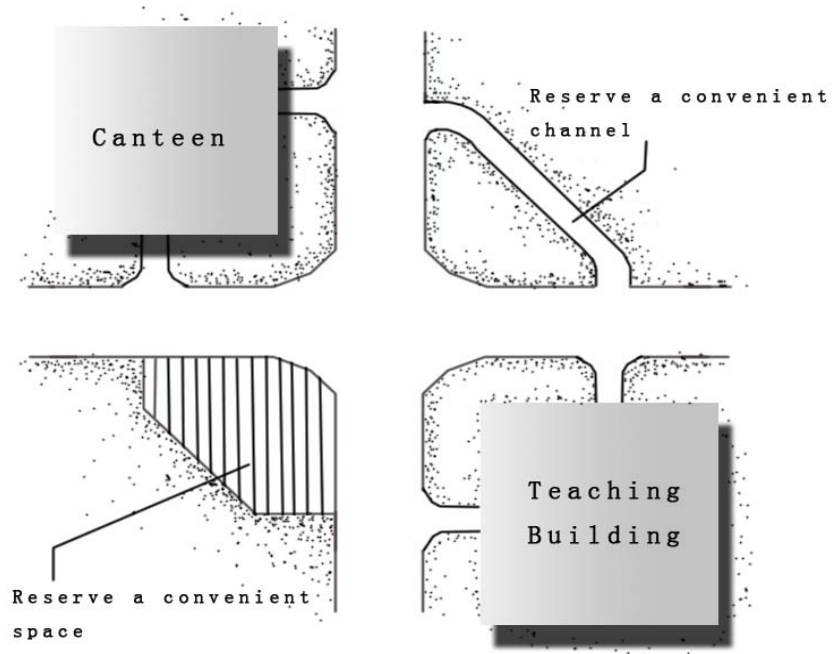

FIGUREII. THE CAMPUS TRAFFIC PLANNING.

\section{Control the Safe Distance Between Vegetation To Users}

In garden use, People unbend arm length is about $50-80 \mathrm{~cm}$, so the location of plants from garden road at least $1 \mathrm{~m}$ above. If the ornamental plant area is larger, it should increase the vertical height; make the platform plant viewing area which is convenient for visitors watch clearly.

\section{Perfect Landscape Marking System}

According to many years of experience in engineering practice, in this paper environmental labeling system is divided into the scenic labeling system, scenic spots identification system and risk warning system., as shown in the below (FIGUREIII).

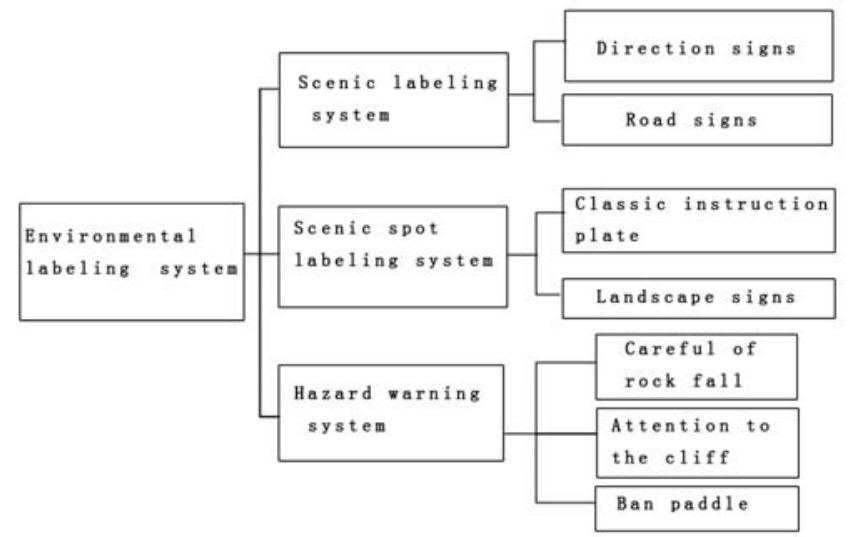

FIGUREIII. LANDSCAPE MARKING SYSTEM ANALYSIS.

\section{E. Using The General Design Concept}

Universal design is the design. It designs products and the environment without adaptability and specificity, can be used by as many people as possible even better to all people[4](MeiSi RON). It must design the ramp for the disabled, for example: entrance gate entrance, wicket, toilet, etc. Grade i should satisfy the standard of barrier-free design, and namely the slope range is from 1:20 to1: 8. large public buildings footpath is greater than $1.80 \mathrm{~m}$; small and medium-sized public buildings footpath is greater than $1.50 \mathrm{~m}$; wicket, clearing the mouth wheelchair channel is greater than $0.90 \mathrm{~m}$.

\section{F. Waterfront Green Space Boundary Treatment}

As far as possible choose ecological revetment in revetment design, consider the lawn landscape into the water and waterfront landscape stone landscape; improve the growth environment of aquatic plants, it helpful for restoration of natural water system and sustainable development; at the same time, placing stone and lawn effectively separated buffer water and public activity space, and avoid the user to the water destruction to dispose of garbage.

\section{G. Enrich Vegetation Layers of Road Greening}

When the road green design is beginning, the first thing to do is to avoid horizontally crossing the dangerous of the masses. Through the collocation of trees, shrubs, flowers and plants, strengthening the vertical design, increasing the thickness plant groups, enriching plant community level, fully separating roads, all these measures avoid the risk of mass through the green land and protect the integrity of the road landscape.

\section{ACKNOWLEDGMENT}

The paper is supported by the school of landscape architecture, Beijing University of Agriculture, Peking, China; Beijing agronomy degree and graduate education reform and development program (2015 yjs008) "based on strengthening the practical training as a platform, by the enterprise and key laboratory of graduate student training mode" research achievements.

\section{REFERENCE}

[1] An Xu. Mass destruction and garden design search [D]. Central South University of Forestry And Technology,2004

[2] Liu zhineng. Study On Park Open Space and People's Behavior [D].Tian Jin University,2007

[3] Albert j.lats leach. The public behavior and park design[M].Beijing: China's construction industry Press,1983.26.

[4] Codes for accessibility design GB 50763-2012[S].2012. 